\title{
Cinema de poesia: os germens poéticos que fecundam Lavoura arcaica
}

Acir Dias da Silva

Doutor em Educação pela Universidade Estadual de Campinas. Professor titular da Universidade Estadual do Oeste do Paraná. Professor do Programa de Pós-graduação Stricto Sensu - Mestrado em Letras - Área de Concentração em Linguagem e Sociedade, da Unioeste. Pesquisador Associado do Laboratório de Estudos Audiovisuais (OLHO), da Universidade de Campinas.

E-mail: acirdias@yahoo.com.br

Deise Ellen Piatti

Mestra em Letras - área de concentração em Linguagem e Sociedade da Unioeste - linha de pesquisa em Linguagem Literária e interfaces sociais: Estudos Comparados, pela Capes. Técnica Arte-educadora do Programa Atitude da Secretaria de Estado da Criança e Juventude do Governo do Paraná e da Prefeitura de Cascavel-PR.

E-mail: deisepibic@hotmail.com

Resumo: O que é cinema de poesia e em que aspectos ele se diferencia do cinema de prosa? Em que medida Lavoura arcaica (2001), filme de Luiz Fernando Carvalho, se configura como cinema de poesia? Com este aprofundamento de estudo, acreditamos ter encontrado uma resposta que, certamente, não esgota tais questões, mas nos dá suporte suficiente para aventurarmo-nos em busca de maiores construções de sentidos sobre o cinema de poesia.

Palavras-chave: Lavoura arcaica, cinema de poesia, memória estética.
Abstract: What does cinema of poetry means and in which aspects it differentiates from the cinema of prose? In which ways does the Luiz Fernando Carvalho's movie, Lavoura arcaica (2001), configurates itself as a cinema of poetry? We believe that with this profound study, we have found an answer that, certainly, doesn't silence some questions, but gives us enough support to venture ourselves in the pursuit of more constructions of meanings about the cinema of poetry

Keywords: Lavoura arcaica, cinema of poetry, esthetic memory.
Recebido: 16.06 .2009

Aprovado: 08.12.2009

1. PASOLINI, Pier Paolo. Cinema de prosa e cinema de poesia. In: GOLDFARB, José Luiz (Org.). Diálogo com Pasolini - Escritos (1957-1984). Tradução de Nordana Benetazzo. São Paulo: Nova Stella, 1986. p. 104. 
2. LAVOURA arcaica. Direção de Luiz Fernando Carvalho. Brasil: Europa Filmes, 2001. 1 DVD (171 $\mathrm{min})$, son., color.

3. PASOLINI, Pier Paolo. Empirismo hereje. Lisboa: Assírio \& Alvim, 1982. p. 151.

4. NASSAR, Raduan. Lavoura arcaica. São Paulo: Companhia das Letras, 1989. p. 87.
No cinema de poesia, a câmera é sentida pelo espectador de duas maneiras: ao ser movimentada na mão, mas também quando se encontra estática. Neste caso, o efeito de ilusão ao que se quer dar ênfase é o processo de introspecção, ou seja, a câmera sem ação é posta em frente às personagens, quando se quer enfatizar seu pensar. Em Lavoura arcaica ${ }^{2}$ (2001), a ausência de ação da câmera surge com este propósito quando do encontro de André - o narrador-personagem - e Pedro, seu irmão, no quarto de pensão, onde o narrador dá início ao processo de rememoração, em que suas memórias e imaginação do passado, bem como a narração presentificada, convivem. Em tais tomadas, a câmera sem movimento e os enquadramentos fechados nos rostos dos personagens constituem meios pelos quais é possível expressar os processos internos do narrador-personagem. Nelas a poesia lhes é interna, obtida por outros meios. Isso significa que Lavoura arcaica consiste num filme que não é poesia pura e unicamente. Ele é também narrativo: sua língua é também a da prosa. Constitui, portanto, uma prosa poética. Diz Pasolini que:

[...] a formação de uma língua da poesia cinematográfica implica, por conseguinte, a possibilidade de criar, pelo contrário, pseudonarrativas escritas na língua da poesia: a possibilidade, em suma, de uma prosa de arte, de uma série de páginas líricas, cuja subjetividade será garantida pelo uso do pretexto da Subjetiva Indireta Livre: onde o verdadeiro protagonista é o estilo ${ }^{3}$.

Já a câmera em movimento terá seu deslocamento perceptível ao espectador quando houver necessidade de expressar não só o deslocamento da personagem, mas o movimento que implica um deslocamento de sua perspectiva, deslocamento de percepção de mundo e de ordenação da realidade. Entretanto, foi dito que estes são dois meios para atingir tal efeito. Estão eles, contudo, agindo em conformidade com inúmeros outros recursos, dentre os quais estão os cinemas (unidade mínima de significação da língua cinematográfica, ao que, nas línguas escrito-faladas, corresponde o fonema), que compõem os enquadramentos no quarto de pensão: o lençol amarrotado, roupas espalhadas, a pouca iluminação; enfim, tudo num plano é significativo, tudo converge para construção de sentidos que expressam a disposição do espírito de André.

Lavoura arcaica é feito a partir da obra homônima de Raduan Nassar, publicada no ano de 1975. O romance tem como conflito a luta entre a liberdade e a tradição no entorno familiar. A história é narrada em primeira pessoa pelo narrador-personagem André. Este se encontra num tempo distante ao dos fatos narrados, no qual ele rememora instantes da infância passada na fazenda junto ao avô, ao pai, Iohána, à mãe e aos irmãos Pedro, o primogênito, Rosa, Zuleika, Huda, Lula, o caçula, e Ana, por quem se apaixona e tem, na adolescência, um relacionamento incestuoso. André, epilético, é também o filho que entra em guerra contra as leis do pai e declara-se o "Profeta de sua própria história", aquele que toma as rédeas de sua vida. Tendo sido consumada sexualmente a relação entre André e Ana, o protagonista foge de casa e se exila em um quarto de pensão, numa vila. Lá, ele passa a viver tal como um fora da lei, num mundo de orgias, sob o domínio das paixões, da miséria, da solidão. Neste 
outro espaço, destituído das leis do pai e do olhar apreensivo do irmão mais velho, André goza de liberdade, mas convicto de que esta não é mais do que uma paz precária, um sono provisório. Diz ele: "Quanta sonolência, quanto torpor, quanto pesadelo nessa adolescência!"5. No desfecho da narrativa, conduzido por Pedro, André retorna ao lar da família, submisso. No diálogo que tem com o pai, o filho pródigo tenta fazer-se entender, expondo-lhe as razões pelas quais fugira de casa, e mostrar o seu ponto de vista, que vai contra o do patriarca. André não obtém resultado algum e reconhece: "Quanta amargura meu pai juntava à sua cólera! E que veleidade a minha, expor-lhe a carcaça de um pensamento, ter triturado na mesa imprópria uns fiapos de ossos, tão minguados diante da força poderosa de sua figura à cabeceira"6.

\section{TRADUÇÃO: NOVA PRODUÇÃO DE SENTIDOS}

Haroldo de Campos considera a tradução não só enquanto transcriação, mas ainda como processo de transculturação, já que não só o texto, mas a série cultural transtextualizada no imbricar-se de tempos e espaços literários diversos. Para o autor, a tradução é antes uma desconstrução, uma violenta apropriação e leitura conscientemente seletiva do substrato literário da obra traduzida ${ }^{7}$. Roman Jakobson considera a tradução como um processo de transcriação. Essa noção jakobsoniana valoriza, por um lado, a forma como parte essencial na determinação do conteúdo da obra e, por outro lado, propõe uma abolição das fronteiras entre as diferentes manifestações artísticas, uma vez que não se restringe à obra de arte verbal. É também o conceito jakobsoniano de "transposição criativa” - a tradução capaz de reproduzir na outra língua o elemento especificamente poético ${ }^{8}$.

Tradução ${ }^{9}$ do romance, o filme narra uma história tecida pelas diferenças, pelos contrastes humanos, e estas diferenças se fazem sentir, por exemplo, não pura e simplesmente como um jogo de claro e escuro no qual transita a luz das tomadas. Trata-se, antes, de um sentimento claro e de um sentimento escuro, da visão de espaços exteriores e interiores ao próprio corpo de André, deslocamentos dos estados de sua alma.

Em algumas sequências no quarto da pensão, os corpos de André e de Pedro são fragmentados pelo close até que ambos sejam reduzidos à meia face; nada mais que isso é revelado ao espectador. Esta fragmentação de seus corpos alude ao estilhaçamento do núcleo familiar e dos sentimentos do narrador, um isolamento físico e emocional que evidencia o processo conturbado o qual, ele, André, vivencia naquele instante. Os primeiríssimos planos das sequências no quarto da pensão visam ainda à desconstrução da percepção domesticada do espectador que, ante eles, sentirá um estranhamento em relação às imagens projetadas. Diz Jean Epstein que:

[...] o primeiro plano fere também de outro modo a ordem familiar das aparências. A imagem de um olho, de uma boca, que ocupa toda a tela - não só porque aumentada em trezentas vezes, mas também porque vista fora da comunidade

\footnotetext{
5. Ibid., p. 70.

6. Ibid., p. 168.

7. LAGES, Susana Kampff. Walter Benjamin: tradução e melancolia. 1. ed., 1. reimp. São Paulo: Edusp, 2007. p. 90-91.

8. Ibid., p. 89.

9. Assim, por tradução, compreendemos nova produção de sentidos.
} 
comunicação \& educação • Ano XV • número 3 • set/dez 2010

10. EPSTEIN, Jean. Écrits de Jean Eptein sur le cinéma (Escritos de Jean Eptein sobre o cinema). Paris: Seghers, 1975. Citado por: XAVIER, Ismail. 0 discurso cinematográfico: a opacidade e a transparência. 3. ed. São Paulo: Paz e Terra, 2005. p. 109

orgânica -, assume um caráter de autonomia animal. Este olho, estes dedos, estes lábios, já são seres que possuem, cada um, suas próprias fronteiras, seus movimentos, sua vida, sua finalidade próprias. Eles existem em $\mathrm{si}^{10}$.

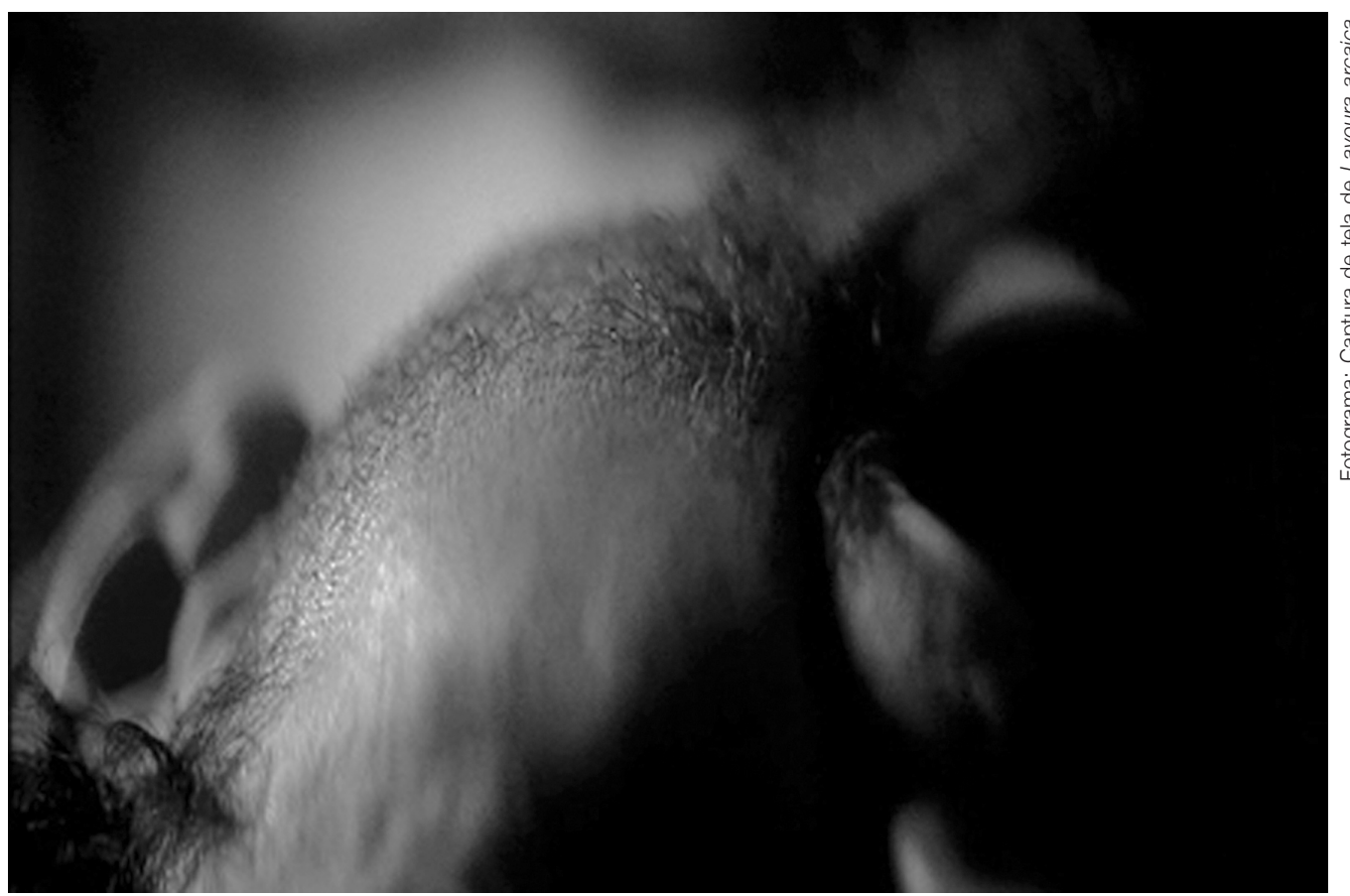

Sob lente anamórfica, o close de André.

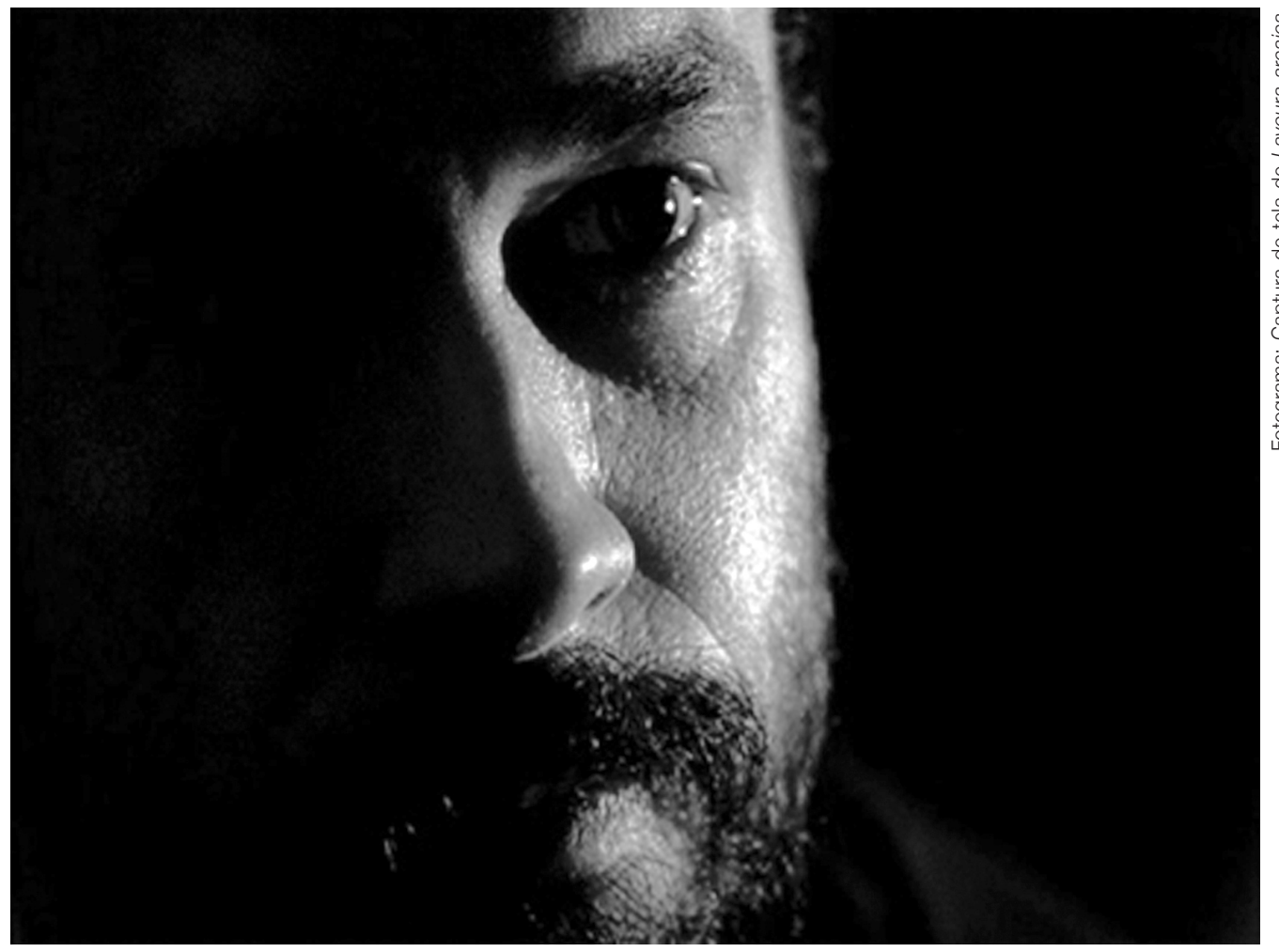

Close de Pedro numa atmosfera tétrica, enegrecida e purgatória do quarto de pensão. 
Evoquemos outro fragmento do filme: a fábula do Sermão do faminto. Nesta visão, ao personificar-se no servo que se volta contra seu senhor e anfitrião, André é representado numa quase indiscernível associação com as formas humanas: o close, a fotografia em preto e branco, formas alongadas e desfocadas dão o tom e expressam o discurso do narrador em uma de suas visões apocalípticas.

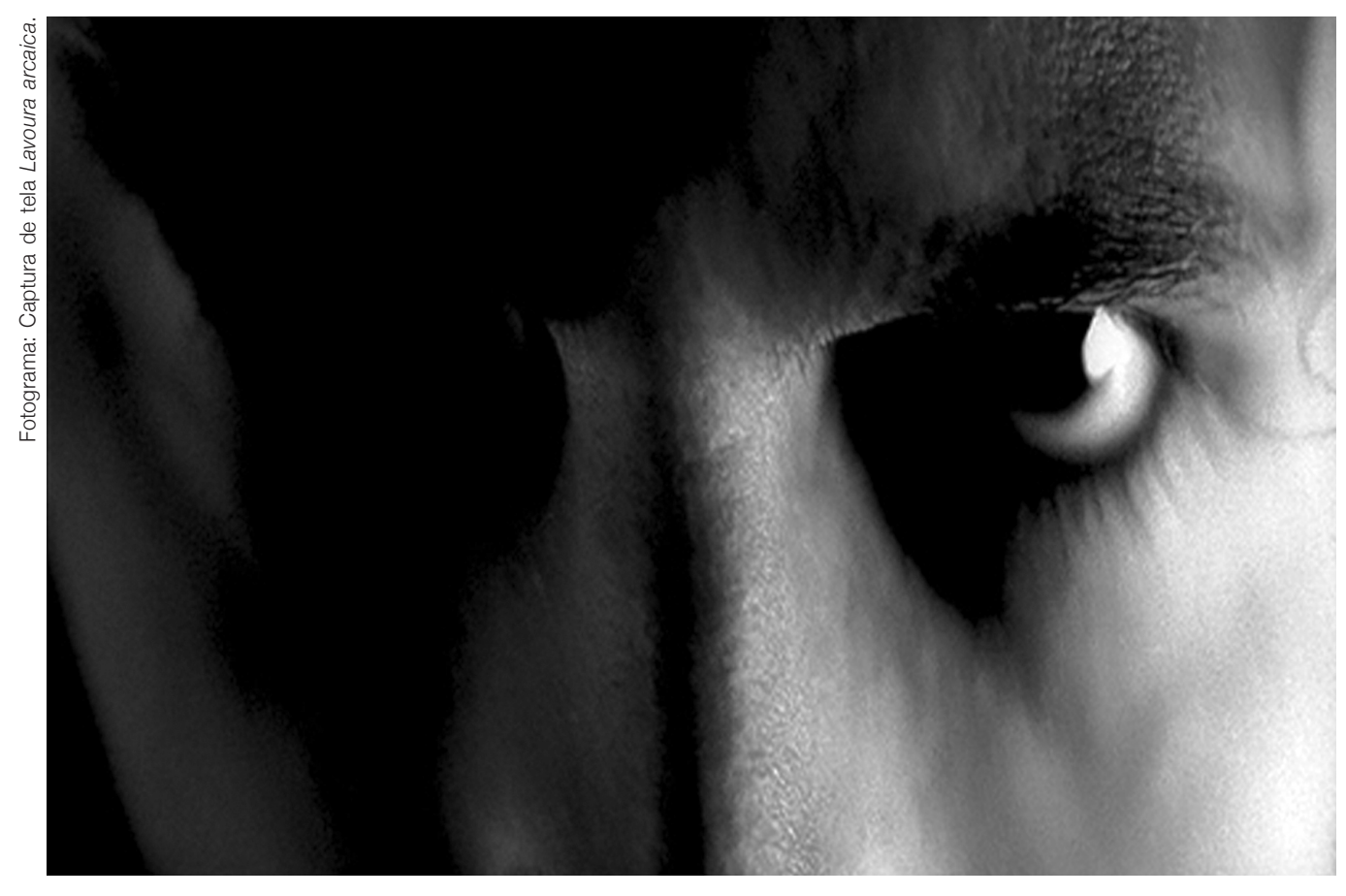

André no papel do servo na fábula do Sermão do faminto.

Disse o diretor Luiz Fernando que o princípio de contestação, enquanto elemento que se materializa por meio da linguagem, permeou todo o trabalho de produção do filme ${ }^{11}$. Essa contestação da naturalização dos sentidos e busca pela linguagem primordial é também discurso gritante na obra de Raduan Nassar: ela é parte das necessidades de se fazer reconhecido no mundo e de se expressar, pelas quais clama André. Ora, o discurso de André consiste numa liberação de uma verdade subterrânea, de um ponto de vista tido como clandestino, razão pela qual Luiz Fernando o traduz de modo não naturalizado.

As sequências de Lavoura arcaica estão em constante diálogo umas com as outras. Existe entre elas um efeito de imagem já contido na anterior, que corporifica a que está por vir. Esse efeito de imagem pode ser qualquer elemento do conjunto da linguagem que faz brotar a sequência seguinte. Em muitas cenas, os cortes desaparecem por meio do som, de modo que este atua também como imagem, revelando-nos coisas. Essa forma de montagem se dá de tal modo que os cortes deixam de ser um efeito de sentido para se transformarem em ilusão, em elemento dramático que instaura uma problematização na linguagem do real do cinema. E é assim que se materializa, por meio da montagem, a linguagem tubular do livro, no qual há o convívio dos quatro tempos da vida do

11. MARTINS FILHO, Plínio (Ed.). Luiz Fernando Carvalho sobre o filme Lavoura arcaica. Cotia, SP: Ateliê Editorial, 2002. 
12. Ibid., p. 66.

13. ALMEIDA, Milton José de. Cinema: arte da memória. Campinas: Autores Associados, 1999. p. 38.

14. Id. O real, a linguagem da realidade, o cinema. Boletim Diálogos: cinema e escola. Rio de Janeiro: TV Escola/Salto para o Futuro, 2005. p. 3. Disponível em: <http:// www.tvebrasil.com.br/ salto/boletins $2005 / \mathrm{rslc} /$ tetxt5.htm>. Acesso em: 10 jun. 2008 narrador-personagem: André menino, André adolescente, sua estadia na pensão e o momento do retorno para a fazenda. Todas estas situações surgem a este narrador enquanto imagens rememoradas num tempo distante. A montagem obedece ao fluxo com que tais imagens são rememoradas; e é deste movimento, no qual uma imagem, uma lembrança, sai de dentro da outra para gerar o todo, que se origina o seu movimento sensorial. Neste percurso, vemos que, por fim, é a linguagem particular do inconsciente de André que dá o tom da narrativa. $\mathrm{O}$ momento certo da passagem das sequências, o jogo de luz e sombra, cada movimento da câmera, enfim, toda a narrativa cinematográfica privilegia o mundo interior de André, que é revelado num tempo da reflexão, e não da contemplação. "Montagem é reflexão", diz Luiz Fernando Carvalho ${ }^{12}$.

Nos instantes em que, de fato, o diretor opta pela aparição do corte, isso se faz de modo autêntico, com o uso do corte brusco, para que o espectador o sinta emocionalmente. Por meio desses espaços existentes no momento da passagem de uma sequência a outra, nas horas de total negritude ou de claridade ofuscante, o espectador é convidado, emocionalmente, para tecer a rede de significados do filme, à vontade - bem como de sua própria vida. É também por este motivo que o filme transcende a adaptação de uma obra literária para o cinema e torna-se tradução-poética cuja linguagem não é representação, mas revelação criativa. Segundo Milton José de Almeida:

Este intervalo que vai dar sentido ao que está sendo narrado não é um intervalo vazio. Ao contrário, é o mais pleno: nele acontece e age a história do espectador, a história como memória e sentimentos coletivos, prazeres únicos e prazeres compartilhados. Eu e todos. Um intervalo em que a ilusão de ser único tenciona a ilusão de ser histórico. E a inteligibilidade de um filme acontece nesse misterioso intervalo, entre os cortes e as cenas escolhidas para serem vistas, editadas e montadas, de acordo com a possível e efetiva produção final de um filme, com tudo de artístico e de ideológico do momento de produção desse filme ${ }^{13}$.

Todos os elementos do filme são traduções da sua referência verbal contidas no livro. É por meio da verbalização que as imagens literárias produzem uma fotografia da qual se extrai sua visualidade, elemento que objetivamente não está no livro, mas é gerado por suas imagens literárias e pela memória do leitor. A visualidade também está na história da própria arte, na forma como os contrastes, o branco, o preto absoluto, ressurgem em nossa memória estética. Assim, percebe-se que Luiz Fernando Carvalho não privilegiou o pictórico, que não gera os desaparecimentos de imagens necessários ao fluxo da imaginação - e veja-se o porquê da importância deste posicionamento do diretor de cinema no processo de edição de um filme. No artigo $O$ real, a linguagem da realidade, o cinema ${ }^{14}$, diz Almeida que ver um filme é também um ato político, um exercício por meio do qual são atribuídos novos significados ao filme, aos símbolos invisíveis e subentendidos nas imagens nele exibidas. E tudo o que aparece na tela alude à outra coisa além do que está sendo visto: a mundos imaginados, reais, sonhados, do passado, do presente, e a mundos presentes no esquecimento da memória. As imagens do cinema são dotadas de uma potência 
do real, ou seja, de uma visualidade, e, quando atualizadas pelo leitor/espectador, elas ressurgirão em alusão e em recordação. "Cinema é arte da Memória e da Alusão"15, diz Almeida. Já as imagens de Lavoura arcaica, ao contrário, descendem de pintores e diretores que, também eles, trabalharam na criação de uma fabulação do real, de uma transfiguração.

O discurso em Lavoura arcaica surge como montagem figurativa ${ }^{16}$ que interrompe o fluxo de acontecimentos e marca a intervenção do sujeito do discurso por meio da inserção de planos que destroem a continuidade do espaço diegético. Através da montagem, os planos aparecem de forma justaposta, e não encadeados, de modo que as imagens se tornam unidades complexas de significação que ultrapassam o nível denotativo e passam a significar algo não contido em cada uma das representações; como, por exemplo, as alusões às pinturas de El Greco, Caravaggio, Ticiano, Van Gog, Degas, Murch, Millet, Cézanne e outros, conforme aponta Luiz Fernando Carvalho ${ }^{17}$.

Neste sentido, na sequência em que André revela a Pedro sua doença e a discordância em relação aos valores do pai, é possível aludir visualmente à tela Abertura do Quinto Selo do Apocalipse (c. 1608-14), de El Greco, e, consequentemente, à ideia do apocalipse enquanto revelação e fim de um tempo, a saber, do tempo interno à casa da família, o tempo do pai, do poder. Na forma de alusão visual e estética, este tema apocalíptico surge no filme como visões de André. Ou seja, um simbolismo religioso utilizado por Luiz Fernando Carvalho tendo por base um momento apocalíptico que alude à queda da casa e à destruição da família. Vejamos mais detalhadamente uma possível aproximação entre o estilo de El Greco e uma sequência do filme.

A tela A Abertura do Quinto Selo do Apocalipse é uma das pinturas mais importantes de El Greco. Representa a passagem do Apocalipse de João, e é o próprio santo que vemos no lado esquerdo do quadro, em êxtase visionário, erguendo olhos e braços aos céus num gesto profético. A passagem é aquela em que o cordeiro intima a João que "venha e veja" a abertura dos sete selos:

Quando abriu o quinto selo, vi sob o altar as almas dos que tinham sido imolados por causa da Palavra de Deus e do testemunho que dela tinham prestado. E eles clamaram em alta voz:

"Até quando, ó Senhor santo e verdadeiro, tardarás a fazer justiça, vingando nosso sangue contra os habitantes da terra?".

A cada um deles foi dada, então, uma veste branca e foi-lhes dito, também, que repousassem por mais um pouco de tempo, até que se completasse o número dos seus companheiros e irmãos, que seriam mortos como eles ${ }^{18}$.

$\mathrm{Na}$ tela, as figuras nuas, com gestos excitados, são, portanto, os mártires que se levantam para receber a prenda celestial dos mantos brancos. Por certo, é persuasiva essa visão do Juízo Final, quando os próprios santos clamam pela
15. Ibid.

16. Sobre o conceito de montagem figurativa, ver: XAVIER, O discurso cinematográfico, cit., $p$. 130-132.

17. MARTINS FILHO, op. cit., p. 101

18. Apocalipse 6,9-11. Bíblia de Jerusalém. Tradução de Euclides M. Balancin et al. São Paulo: Paulus, 1985 
destruição do mundo. Também não é difícil ver que El Greco tinha aprendido muito com os métodos de composição de Tintoretto, ou seja, não ortodoxos e soturnos, como as formas alongadas ${ }^{19}$.

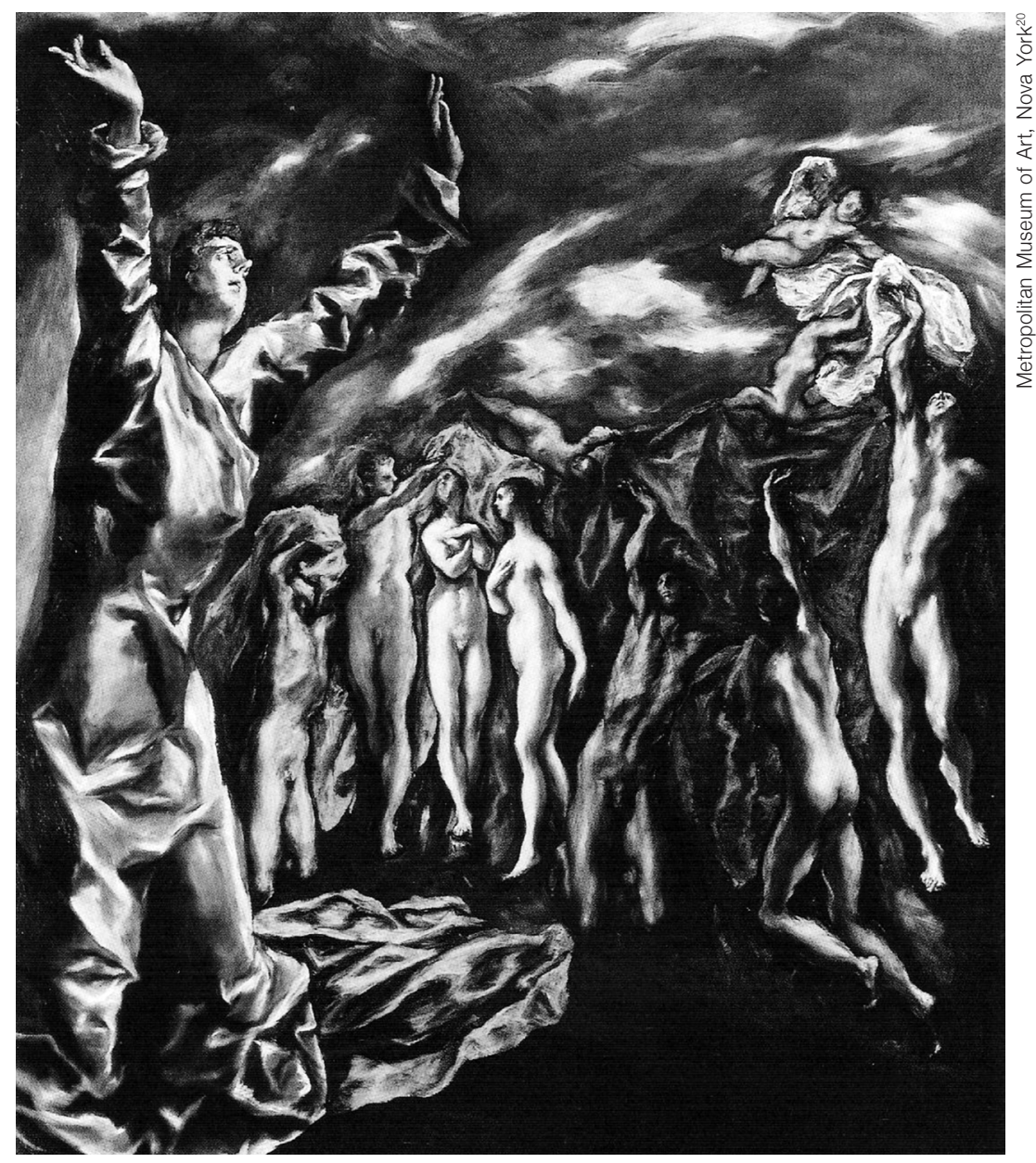

El Greco. A Abertura do Quinto Selo do Apocalipse. Óleo sobre tela, 224,5 x 192,8 cm.

Apocalipse quer dizer desvelar, revelação feita por Jesus Cristo, que se refere a ele mesmo e é dirigida ao apóstolo João. De modo geral, nos textos apócrifos encontramos a imagem de Cristo associada à imagem do Deus Pai, de maneira que, estando elas justapostas, o discurso revelado pelo primeiro implica um protesto contra o culto imperial ante a imagem do segundo. Florescente em

19. GOMBRICH, Sir Ernst. História da arte. Rio de Janeiro: LTC Editora, 1999.

20. Ibid., p. 372.

21. LELOUP, Jean-Yves. O ícone: uma escola do olhar. Tradução de Martha Gouveia da Cruz. São Paulo: Editora Unesp, 2006. p. 148 épocas de crise, o gênero literário apocalíptico mais conhecido é o que o apóstolo João escreveu em Patmos e que completa o Novo Testamento ${ }^{21}$. Em Lavoura arcaica, a imagem de André alude a Jesus Cristo, quando, transfigurado, conta a Pedro ser epilético. Este é o momento apocalíptico no qual são revelados ao irmão primogênito os segredos da alma daquele irmão acometido, cuja vida lhe fora amputada pelas leis do pai.

A sequência é composta da montagem de planos que registram André e Pedro no quarto de pensão e de imagens que são devaneios do inconsciente desse narrador em processo rememorativo. Nesse momento, imaginação e 
lembrança se fundem em formas desconexas, alongadas, em cores fúnebres de uma estética tétrica; modo pelo qual a linguagem manifesta o cosmo do caos interior de André. Assim, toda a aparente desordem das imagens nada mais é que a ordem secreta do inconsciente de André, “[...] pois em todo caos há um cosmo, em toda desordem uma ordem secreta, em todo capricho uma lei permanente, uma vez que o que atua repousa no seu oposto"22. Ora, antes mesmo de ser exteriorizado, o discurso interior é alógico, está no estágio da estrutura imagético-sensorial, que contém particularidades estruturais e leis próprias.

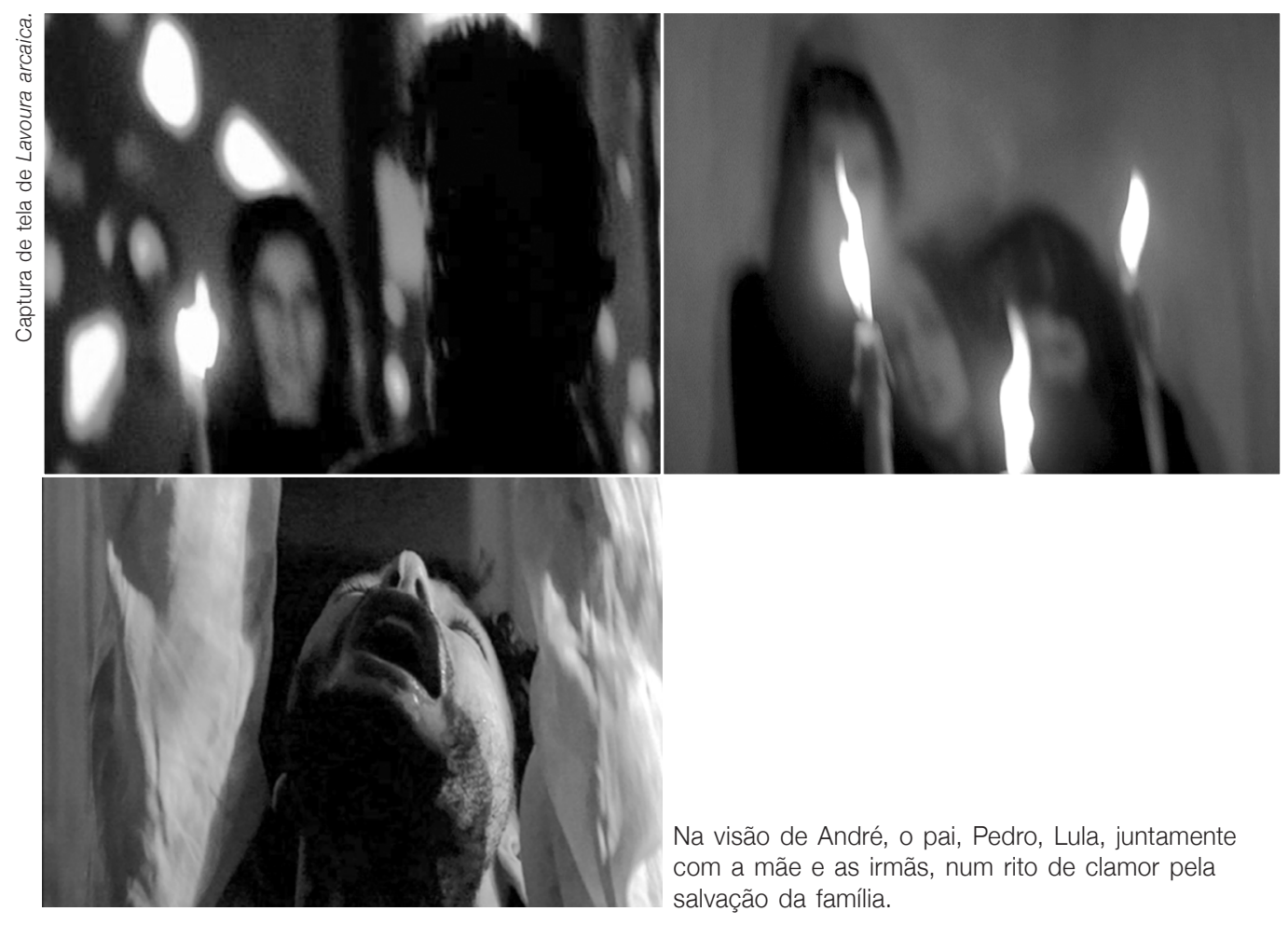

Por fim, Pasolini dirá que é possível uma língua da poesia no cinema por meio da técnica do discurso indireto livre ou, traduzido para a língua do cinema, por meio da subjetiva indireta livre*. Na literatura, o discurso indireto livre foi expresso abundantemente a partir do século XIX por meio dos discursos revividos:

[...] característica constante de todos os discursos revividos é a de o autor não poder abstrair-se de uma certa (sic) consciência sociológica do meio que evoca: é, com efeito, a condição social da personagem que determina a sua língua (linguagem especializada, calão, dialecto, língua dialectizada ${ }^{23}$.

Então cabe perguntar: em que consiste esse discurso indireto livre cinematográfico? "Trata-se, muito simplesmente, da imersão do autor na alma da sua personagem e na adopção, portanto, pelo autor não só da sua psicologia como da língua daquela" ${ }^{24}$. A expressão dessa visão interior exige necessariamente uma língua especial, expressões linguísticas específicas, com seus requintes estilísticos e seus tecnicismos, presentes em sua inspiração. Ou seja, a possibilidade de mergulho em uma personagem caracteriza-se não como operação linguística, mas,

22. JUNG, Carl Gustav. O espírito na arte e na ciência. Tradução de Maria Luiza Appy et al. Petrópolis: Vozes, 2000. p. 41.

* Mais sobre subjetiva indireta livre, ver: <http:// cinemapode.blogspot. com/2009/04/marguerite-duras-e-subjetiva-indireta.html>. N.E.

23. PASOLINI, op. cit., p. 144.

24. Ibid., p. 145. 
comunicação \& educação • Ano XV • número 3 • set/dez 2010

sim, estilística, a saber: uma tradição técnico-estilística. É por meio do estilo que é possível diferenciar sua psicologia. Na prática, será por meio de certos modos característicos da linguagem da poesia. No cinema, sendo a base fundamental da subjetiva indireta livre um princípio estilístico, dirá Pasolini que: "[...] ela liberta as possibilidades expressivas sufocadas pela tradicional convenção narrativa, numa espécie de regresso às origens: até encontrar nos meios técnicos do cinema as suas qualidades oníricas, bárbaras, irregulares, agressivas e visionárias" ${ }^{\prime 2}$. Assim, vemos que o efeito estilístico de Lavoura arcaica é uma longa subjetiva indireta livre, que se assenta no estado de alma dominante do protagonista; estado este que oscila desde ataques epiléticos até momentos de doçura junto à mãe na fazenda: o estilo converge para estes dois polos sentimentais extremos.

\section{REFERÊNCIAS BIBLIOGRÁFICAS}

ALMEIDA, Milton José de. Cinema: arte da memória. Campinas: Autores Associados, 1999.

BÍBLIA DE JERUSALÉM. Tradução de Euclides M. Balancin et al. São Paulo: Paulus, 1985.

GOLDFARB, José Luiz (Org.). Diálogo com Pasolini - Escritos (1957-1984). Tradução de Nordana Benetazzo. São Paulo: Nova Stella, 1986.

GOMBRICH, Sir Ernst. História da arte. Rio de Janeiro: LTC Editora, 1999.

JUNG, Carl Gustav. O espírito na arte e na ciência. Tradução de Maria Luiza Appy et al. Petrópolis: Vozes, 2000.

LAGES, Susana Kampff. Walter Benjamin: tradução e melancolia. 1. ed., 1. reimp., São Paulo: Edusp, 2007.

LELOUP, Jean-Yves. O ícone: uma escola do olhar. Tradução de Martha Gouveia da Cruz. São Paulo: Editora Unesp, 2006.

MARTINS FILHO, Plínio (Ed.). Luiz Fernando Carvalho sobre o filme Lavoura arcaica. Cotia, SP: Ateliê Editorial, 2002.

NASSAR, Raduan. Lavoura arcaica. São Paulo: Companhia das Letras, 1989.

PASOLINI, Pier Paolo. Empirismo hereje. Lisboa: Assírio \& Alvim, 1982.

XAVIER, Ismail. O discurso cinematográfico: a opacidade e a transparência. 3. ed. São Paulo: Paz e Terra, 2005.

\section{Endereço eletrônico}

ALMEIDA, Milton José de. O real, a linguagem da realidade, o cinema. Boletim Diálogos: cinema e escola. Rio de Janeiro: TV Escola/Salto para o Futuro, 2005. Disponível em: <http://www.tvebrasil.com.br/salto/boletins2005/rslc/tetxt5.htm>. 